J. Dairy Sci. 97:4659-4659

http://dx.doi.org/10.3168/jds.2014-97-7-4659

(C) American Dairy Science Association ${ }^{\circledR}, 2014$.

\title{
Erratum to "The effect of rumen digesta inoculation on the time course of recovery from classical diet-induced milk fat depression in dairy cows" (J. Dairy Sci. 97:3752-3760)
}

D. E. Rico, Y. Ying, A. R. Clarke, and K. J. Harvatine

On page 3754 of the print version, reference was made to Supplemental Table S2 but should have referenced Supplemental Figure S2. All supplemental tables and figures are available at http://dx.doi.org/10.3168/ jds.2013-7342.

\section{REFERENCES}

Rico, D. E., Y. Ying, A. R. Clarke, and K. J. Harvatine. 2014. The effect of rumen digesta inoculation on the time course of recovery from classical diet-induced milk fat depression in dairy cows. J. Dairy Sci. 97(6):3752-3760. 10.3168/jds.2013-7342. 